\title{
State Sovereignty, Associational Interests, and Collective Religious Liberty
}

Chapter 5 of Cécile Laborde's excellent book Liberalism's Religion is focused upon the freedom and autonomy of religious associations within liberal democratic societies. ${ }^{1}$ Laborde makes two main arguments.

First, she rejects theories of 'sphere sovereignty' or 'religious institutionalism', according to which associations like churches have a prepolitical authority and jurisdiction that limits the state's jurisdiction (161171). She insists that the state is the sole sovereign, and has the unique authority to define both its own jurisdiction and the rights and freedoms of all other associations. Controversies over the state's legitimate jurisdictional authority are non-starters.

Second, Laborde develops a view of justice in this area: of the rights and freedoms that religious groups ought to be granted (171-196). In keeping with her 'disaggregation approach', ' she argues that groups' rights are derived from the liberal value of freedom of association. What matters is not what makes groups 'religious', but the specific interests and relationships promoted and protected by associations, which can ground various rights. Laborde argues that two kinds of interests can justify special associational rights. 'Coherence interests' justify groups' rights to choose their own membership and leadership, leading to some legal exemptions. 'Competence interests' justify a degree of judicial deference in relation to groups' decisions.

In this paper I will consider these two arguments in turn. With regard to the first, I argue that Laborde makes things too easy for herself, by downplaying the extent to which disputes about how the state ought to exercise its sovereignty can cause fundamental disagreements about the legitimacy of state action. With regard to the second, I argue that Laborde's view of justice is too narrow and provides insufficient protection for religious group freedoms. I also consider how we might fill in the details of an account of judicial deference.

As will become clear, I agree with much of what Laborde says about collective religious liberty, so will not be offering any fundamental critique.

\footnotetext{
${ }^{1}$ Cécile Laborde, Liberalism's Religion (Cambridge, Mass.: Harvard University Press, 2017). All page references in parenthesis in the main text are to this book.

2 Developed throughout Part II of ibid. See also Cécile Laborde, "Religion in the Law: The Disaggregation Approach," Law and Philosophy 34(6) (2015): 581-600.
} 
But my discussion will highlight various important points of disagreement, which would make a significant difference in practice.

\section{Authority, Jurisdiction, and Sovereignty}

Much recent discussion of the freedom and autonomy of religious groups has concerned the question of whether such groups enjoy some degree of sovereignty, or independent authority, such that they in some sense lie outside of the state's jurisdiction and limit its reach. Advocates see this view as a proper recognition of social institutions' independent, prepolitical, existence. Critics usually see it as fundamentally opposed to liberal democratic principles. $^{3}$

Laborde sides with the critics in insisting on the state's sole sovereignty. Only the state represents the interests of all individuals qua individuals, so only it can provide an authoritative resolution to conflicts about justiceincluding about the scope and boundaries of religious group freedom. The state has 'competence-competence'-"the competence to decide the respective areas of competence of associations within it" (162). It determines what counts as public and private, as within the domain of church and state, as religious and secular. Its jurisdiction is not externally limited by the claims of independent 'spheres'. And it has authority "to define its own sphere of competence, as well as that of other institutions" (165, emphasis added). Laborde argues that this is in fact the truly radical claim made by liberal political theory: "The radicalism of liberalism... lies in the fact that it assumes state sovereignty: the state's prerogative decisively to fix and enforce the terms of the social contract" (163).

Despite this claim being radical, Laborde argues that no one in the contemporary debate actually denies it. Talk of religious groups' jurisdictional authority turns out to be rhetorical. It is a way to emphasise the normative force of groups' rightful claims to autonomy, but is not really a denial of the state's competence-competence. Religious institutionalism's apparent threat to the authority of the liberal democratic state is little more than rhetoric. In reality, the dispute is one within liberalism, about the just use of state authority. While the state's sovereignty isn't externally limited by other institutions' jurisdictions, it is internally limited by liberal

\footnotetext{
3 This debate is well reflected in the contributions to Micah Schwartzman, Chad Flanders, and Zoë Robinson, eds., The Rise of Corporate Religious Liberty (New York, NY: Oxford University Press, 2016).
} 
democratic principles themselves. The real debate is about what those principles demand with regard to the freedom of religious groups.

I am unsure whether Laborde is right about this. It is certainly possible that some religious institutionalists do reject the claim that the state enjoys competence-competence. Laborde's helpful conceptualisation might lead some theorists to be clearer that this is indeed the implication of their view.

Even if Laborde is correct that (nearly) all contemporary theorists accept the state's competence-competence, however, the upshot of this is less straightforward than she suggests. Laborde is clear that state sovereignty does not mean that anything goes. The internal limits on sovereignty mean that state actions can be unjust and that they can be illegitimate. Recognising competence-competence does not make all of the state's actions legitimate by definition. If the state violates basic rights, or completely denies groups' any self-determination, then it acts illegitimately. There is no legitimate sovereignty claim here. But there is still a legitimate sovereignty claim when the state acts in ways that some people consider unjust but that do not violate basic rights. Laborde argues that the questions that are of concern to religious institutionalists-such as the application of anti-discrimination legislation to churches-fall into this latter category. They are not cases where the state acts ultra vires, but ones where there is reasonable disagreement about justice.

But some religious institutionalists would go further. They hold that various state actions toward religious groups are illegitimate, not merely unjust. The state acts illegitimately when it fails to grant accommodations, or interferes in the internal life of churches. Such a disagreement about legitimacy is consistent with affirming competence-competence. Even if the state is the only institution that can ultimately settle the bounds, there is a limit to what bounds are legitimate-and some religious institutionalists disagree with Laborde about those limits.

Consider the application of anti-discrimination legislation to churches. Laborde says that in Secularia, one of her ideal-type states that meet the demands of minimal secularism, "anti-discrimination norms constrain the autonomy of religious groups" (151). It is not completely clear what this means. It might mean that churches are not permitted to discriminate on grounds of religion in their choice of ministers. After all, other organisations are not permitted to discriminate on such grounds. This would be a severe restriction of religious freedom, however-which many religious institutionalists would certainly consider illegitimate, not merely 
unjust. Perhaps Laborde does not have this in mind, however. She notes at one point that it is a category mistake to complain about religious groups discriminating on religious grounds-this is necessary if they are to be religious associations at all (179). So perhaps the anti-discrimination norms in Secularia are laws against discrimination on other groundsrace, gender, sexuality. Even then, however, religious institutionalists might consider the application of such laws to churches an illegitimate violation of basic rights of religious freedom. Groups should be able to choose their membership and leadership based on their own beliefs and values, and this should not be considered invidious discrimination. If so, then agreement on competence-competence does not reduce the dispute between religious institutionalists and their critics to reasonable disagreement about justice. The disagreement can be about legitimacy. One can affirm the state's competence-competence while holding that there are tighter restrictions on its legitimate actions than Laborde believes.

Indeed, this is what 'sphere sovereignty' traditionally denoted, on one interpretation. The originator of the term, Abraham Kuyper, recognised the state's proper role in regulating the various spheres within society. He recognised the state's unique meta-jurisdictional authority. But he held that it must respect groups' autonomy. It "may never become an octopus, which stifles the whole of life." 4 The 'octopus state' acts illegitimately, violating groups' and citizens' rights.

This point also applies in the other direction. In Divinitia, Laborde's other ideal-type, "religious groups enjoy extended rights of collective autonomy" (151). Again, it is not clear how extensive these rights are. But presumably they could be extensive enough that some liberal egalitarian critics of religious institutionalism consider them to be illegitimate, due to inadequately protecting individual freedom and equality of opportunity. Indeed, some hold that this point is reached by accommodations already given in the UK and US, such as allowing churches to discriminate on grounds of gender in their ministerial employment decisions. Again, the disagreement here is about legitimacy.

In sum, Laborde makes it too easy for herself by suggesting that recognising competence-competence means that everyone in this debate can agree that their disagreements lie within the domain of reasonable disagreements about justice, such that all of their proposals are within the range of legitimate settlements. Much of the disagreement is over the range

\footnotetext{
${ }^{4}$ Quoted in Nicholas Wolterstorff, The Mighty and The Almighty: An Essay in Political Theology (Cambridge: Cambridge University Press, 2012), p. 162.
} 
of legitimate settlements itself. Agreement on competence-competence, if it indeed obtains, does not detract from the depth or sharpness of that disagreement.

\section{Coherence Interests}

Let's turn to Laborde's own view of justice in this area-her view of the rights that the state ought to grant to religious groups. As I noted, Laborde's account centres on two associational interests: coherence and competence interests. Respect for these interests is required if we are to adequately protect citizens' interest in freedom of association. Nonreligious groups can also have these interests, and thus merit similar rights as religious groups. But I focus exclusively on religious groups here, and discuss the two interests in turn, in this and the next section of the paper. ${ }^{5}$

"Coherence interests refer to associations ability to live by their own standards, purposes and commitments" (175). They "are interests that associations have in sustaining their integrity, that is, their ability to maintain a structure through which their members can pursue the purpose for which they have associated" (178). This includes associations being able to refuse or rescind membership, choose their own leadership and internal structures, and enforce their ethos and standards on members. These freedoms enable individuals to form groups that reflect their shared values, ends, or purposes.

Coherence interests can justify exemptions from some anti-discrimination laws. "When discrimination is grounded in a religious doctrine... courts should treat it as a case of permissible religious discrimination" (180). The Catholic Church should be permitted to appoint only men as priests, and the Jews' Free School should be permitted to reject students that it does not consider Jewish.

Coherence interests thus justify deep associational rights, such as formal exemptions. But Laborde stresses that these rights are narrow, enjoyed only with regard to a strictly delimited range of activities. Indeed, I will argue that she construes these rights too narrowly, due to the conditions

\footnotetext{
${ }^{5}$ For a somewhat different critique of Laborde's account of these two interests, see Andrew Shorten, "May Churches Discriminate?" Journal of Applied Philosophy (forthcoming). Shorten notes some of the same ambiguities that I discuss here, but generally seems worried that Laborde's account will grant too many collective exemptions, while I have the opposite concern.
} 
that she holds need to be met for a group's actions to be protected by these rights.

Laborde says that groups with coherence interests are voluntary associations whose primary mode of association is identificatory. These interests ground rights only when the particular issue in question implicates identificatory coherence-when it reflects the purpose of the association and its members. This has several implications that tightly circumscribe the scope of the rights. I will consider three.

First, a group is an identificatory association only if the individuals that make it up share its aims. "Identificatory associations implicate the identity of their members" (184), allowing members to effectively pursue their values or ideals. This explains why most for-profit organisations do not merit exemptions. They are usually impersonal organisations, where owners and employees are not united by a common ideal or conception of the good.

But not all members of apparently identificatory associations will necessarily share the same aim or purpose either. People join churches for all kinds of reasons - social opportunities, a sense of belonging, in search of a partner, habit, boredom; as well, of course, as to engage in religious worship. Their identity might not be implicated in the group in any significant way. Can the groups' standards nonetheless be imposed on such individuals? Can they be required to comply with those standards, and be disciplined or expelled if they don't?

I think that Laborde would say 'yes', on the grounds that such individuals are still voluntarily part of the group. They have chosen to join, even if their reasons do not align with its central purposes. This voluntary choice makes them subject to its structure and ethos. This seems right. But it means the idea that all members identify with the aims of the group or have their identity implicated by membership is no longer doing the key work in delimiting scope of the group's rights. This might trouble Laborde, since it was this identificatory aspect that was meant to prevent kinds of groups that she does not think ought to have those rights from enjoying them.

Alternatively, one might say that the group cannot enforce its standards on members who do not share its self-defined central purpose. Or even that groups containing such members no longer qualify as identificatory associations, and thus lack coherence interests. But this would surely be too narrow. It would mean that internally diverse groups-practically all groups-would not qualify for exemptions. 
A middle way might be possible. Perhaps associations count as identificatory as long as many members share their central purpose, and the groups' standards can then be enforced on all who voluntary join. We then face questions of how many members must share the purpose, and indeed who defines that purpose, in the face of diversity and internal dissent. Here we run into competence interests, which I discuss in the next section. 6

The second implication of the focus on identificatory association is that there must be a fit between an association's purpose and the people that it intends to serve. "As soon as an organisation claims to serve the public, it is not 'religious' in the sense that matters to standing in exemptions from discrimination claims" (185).

On one reading, this is surely too restrictive. Many religious groups see serving their local community as a central part of their purpose, and engage in various social projects to this end. It is not clear why having a desire to serve the public would mean losing all claims to associational autonomy rights. I do not see why a church would lose its right to appoint only male priests if it adopted this attitude, or started running a soup kitchen.

Perhaps this is not what Laborde has in mind. She focuses on businesses and charities that are open to the public at large, denying that they should be able to refuse to serve certain kinds of people. Groups cannot discriminate in carrying out their external activities. This is still a bit quick, however. Surely Catholic hospitals that do not wish to provide abortion services and family-run bakeries that do not want to provide cakes endorsing gay marriage have at least some coherence-interest-based claim-whether or not it is ultimately weighty enough to justify exemptions. ${ }^{7}$ There are costs to third parties here, of course, which must be balanced against the groups' claim. But that is also true for central exercises of associational freedom, such as refusing membership. So it is not clear why groups should lack any claim for exemptions with regard to activities serving people that do not share their purposes.

\footnotetext{
${ }^{6}$ I further discuss the issue of justifying collective exemptions in the face of internal dissent in my [self-citation redacted].

7 This was certainly the view of the US Supreme Court in Masterpiece Cakeshop v Colorado Civil Rights Commission, 584 U.S. _ (2018). The Court argued that baker Jack Phillips had some claim to an exemption, which must be weighed against the countervailing considerations in a fair and unbiased way. The Colorado Civil Rights Commission lost the case due to its apparent failure to do this.
} 
The third implication is that there must be a fit between the association's main purpose and the specific activity in question. Coherence-based claims to exemptions become weaker as a practice becomes more distant from the group's core purpose. For example, religious employers cannot discriminate on religious, or any other, grounds in relation to employees who do not undertake religious work.

In my view, Laborde is right that the strength of a group's claim varies depending on the centrality of the activity in question, but she overlooks some important difficulties. What counts as a core activity, or as 'religious work'? What if a group sees an apparently secular job as imbued with religious significance?

Consider the case of Obst v. Germany, decided by the European Court of Human Rights in 2010.8 Michael Obst was the Mormon Church's European Director for public affairs. He was dismissed for having an extra-marital affair, a serious sin within the church. He contested his dismissal under Article 8 of the European Convention of Human Rights, the right to respect for private life. The Court found in favour of the church. Obst had a high profile public role, and knew he was expected to follow the church's teaching-indeed, this was stated in his contract. The church was therefore permitted to dismiss him on the otherwise impermissible grounds of adultery.

I am unsure what Laborde would make of this case. Obst's role included representing the church in public, so his actions certainly reflected on the church. The church argued in court that its ability to carry out its mission in accordance with its beliefs would be undermined if it could not make the loyalty of its employees a condition of employment. ${ }^{9}$ But Obst's role was not obviously 'religious'. He was a public relations director, not a minister. Does this mean that his activities were not sufficiently tied to the church's main purpose to ground a claim to exemption in his case?

Another European Court case, Siebenhaar v. Germany, involved a childcare assistant at a Protestant kindergarten, who was dismissed for being an active member of the Universal Church. ${ }^{10}$ Again, the employer won. Siebenhaar had made a commitment to the religious ethos of the Protestant Church, and should have known that involvement in the Universal Church was incompatible with this. But it is not clear that being a

\footnotetext{
8 App no 425/03 (ECtHR, 23 September 2010).

9 This argument was made on behalf of the church by Professor Gerhard Robbers, a prominent German legal theorist.

10 App no 18136/02 (ECtHR, 3 February 2011).
} 
childcare assistant constitutes 'religious work', in Laborde's view, or that the kindergarten is part of the church's 'core purpose'. So she might well disagree with the court. Importantly, this would not merely be a disagreement with the ultimate judgment, but with the idea that the groups in these examples had any claim at all.

This would be too narrow. We should not narrowly construe which activities are covered by coherence interests, or which employees do 'religious work'. Religious associations often engage in a wide range of activities that they see as part of their purposes - which can themselves be multifarious. In sum, while Laborde's concept of coherence interests is useful, it should not be tied to such a narrowly-defined conception of identificatory association or coherence-relevant activities. The churches in both Obst and Sibenhaar had clear coherence interests at stake in the dismissal of these employees. This is not to say that groups should get exemptions in every case they have coherence interests, under my broader construal. Balancing judgments are needed. But we should recognise groups' pro tanto claims in a wider range of cases than Laborde seems to countenance.

Much of the discussion in this section points towards questions of who is to decide. Who defines a group's purposes, or decides which activities reflect those purposes, or which employees do relevantly 'religious' work? It is here that we should turn to Laborde's second associational interest: competence interests.

\section{Competence Interests}

Competence interests relate to "associations' ability to interpret their own standards, purposes and commitments" (175). Associations' decisions are often based upon reasons grounded in their distinctive doctrines, beliefs, or expertise. When disputes about these decisions arise, courts should avoid adjudicating on doctrinal or theological questions. Religious groups have a right to judicial deference to their own understanding of the relevant religious reasons.

The rights justified by competence interests are broad. They apply whenever associations' distinctive expertise or beliefs are behind their decision. But they are also shallow. Courts should defer to groups' judgments of religious reasons, but this does not prelude various kinds of examination of associations' decisions that can be undertaken without entanglement in theological questions. Competence interests do not 
ground jurisdictional immunity, only a level of judicial deference on certain questions.

One crucial question here is what this judicial deference amounts to. What kinds of examination of religious associations' decisions are and are not permitted? Laborde's comments here are very quick. She briefly mentions some kinds of judicial examination that she deems permissible. But the account is underdeveloped, leaving the reader with many questions concerning what these kinds of examination amount to, and what kinds of examination are barred.

In this final section I will briefly sketch a more systematic account of possible kinds of judicial examination, in a case where a former employee brings a complaint against her dismissal, and will consider the permissibility of each at the bar of respect for coherence and competence interests. ${ }^{11}$ I am not sure whether Laborde would agree with my judgments here. I suspect that I am generally a little more cautious about judicial scrutiny, and thus more protective of religious group autonomy. But hopefully my framework can help us identify what is at stake.

First, consider procedural examination of an association's decision. Laborde mentions the European Court case Lombardi Vallauri v. Italy,12 where Court ruled that the dismissal of a professor at a Catholic university for deviating from Catholic orthodoxy had violated his rights, because the decision-making procedure had fallen short of basic procedural fairness (194). Professor Lombardi Vallauri was given no reasons for the decision, and had no chance to defend himself.

The Court here checked whether the associations' decision-making satisfied independent standards of procedural fairness-standards of evidence, transparency, fair warning, right to reply, and so on. There is a range of possibilities with regard to how strict are the standards imposed in such examinations. The Lombardi Vallauri case was rather extreme-the decision flouted even the most minimal standards of procedural fairness. Many cases are less clear-cut: the association gives an employee rather less time to formulate their response to the allegations than we might think fair; reasons for the decision are given, but there is little transparency regarding how the decision was made. Since Laborde only comments on the extreme case, it is not clear how strict a standard she believes courts

\footnotetext{
${ }^{11}$ My comments here are all-too-quick, and my judgments clearly require much more argumentative support. I develop and defend the account in much more detail in my [selfcitation redacted].

${ }^{12}$ App no 39128/05 (ECtHR, 20 October 2009).
} 
should impose. My view is that this standard should be very minimal, to avoid violating competence interests. Only egregious cases such as the Lombardi Vallauri decision would be impugned.

Another kind of procedural examination, which Laborde does not mention, is the court checking that the association followed its own stated disciplinary procedures-that it abided by the procedures it has set for itself. This might look straightforward; for example, the employee has a legitimate complaint if she was not granted the stated two weeks to respond to accusations of malpractice. But matters quickly become complicated here, because assessing whether an association followed its procedures partially involves assessing whether it applied its stated grounds for dismissal. And those grounds will inevitably reflect the association's particular beliefs and values, and thus implicate their competence interests. If 'moral failure' is listed as a ground for dismissal, then it is hard for the court to assess whether the church has followed its procedures without assessing whether the employee has fallen short morally. But it is hard to do that without infringing competence interests, by making judgments about what ought to count as moral failure.

We could make further distinctions. Perhaps the court can assess whether the association has good evidence for the claimed moral failure, while accepting at face value the association's view of what counts as moral failure. For example, the court could accept that adultery is grounds for dismissal in the Mormon Church, but check that they had good evidence that Obst was having an affair. The challenge, of course, is whether courts can limit themselves to identifying and assessing the matters that are within their competence, without also explicitly or implicitly interpreting or assessing groups' doctrines or values in ways that violate competence interests. I will return to this point at the end.

Before that, we should consider whether courts should be permitted to engage in any kind of substantive examination of associations' decisions. We can distinguish three kinds of substantive examination. The most basic involves asking whether the stated reasons for dismissal were pretexual. Did the association actually dismiss the employee because she deviated from orthodoxy in her teaching, or was the real reason simply gender discrimination? Laborde explicitly endorses this kind of assessment, noting that it parallels the sincerity tests commonly applied in cases of individual claims to exemption (193). I think she is right here-again, as long as the standard imposed is fairly minimal. The burden of proof for the association should be low. And courts should not engage in complicated judgments 
regarding precisely what considerations motivated the decisions of each individual involved. But they should be alert to cases where the religious reasons for a decision were only produced subsequent to the employee lodging a complaint and there is clear evidence that other reasons were actually behind the decision.

A second kind of substantive examination is evaluating the reasons for dismissal. There are two versions of this. First, the court could ask whether the reasons for dismissal are good reasons from the perspective of the association itself. Are they justified by its doctrines? A very minimal form of such assessment-requiring the association to show that its decision reflected its values - can be acceptable. But, again, the burden of proof must be low. And the court must not engage in any detailed evaluation of whether the reasons offered are really justified by group's doctrines, or whether the best understanding of its theology supports the decision. This is the kind of theological interpretation and adjudication that is very clearly ruled out by respect for competence interests. Second, a different question the court could ask is whether it considers the reasons for dismissal good ones, based on its own values. This would not directly violate competence interests. But it is ruled out by associations' coherence interests. In effect, it denies that associations are permitted to form around their own purposes and standards. Preventing such state actions is at the heart of protecting religious groups' legitimate autonomy.

Applying this to the cases of Obst and Siebenhaar, I think that the European Court was right to recognise strong associational claims here, in the light of the churches' own understanding of the role of these employees and the nature of their work. Deferring to competence interests means recognising strong coherence-interest-based claims in these cases.

There is also a third kind of substantive examination: evaluating whether the association took into account countervailing considerations, such as the rights and interests of the employee. Laborde endorses this kind of examination, noting that the European Court requires there to have been a weighing process that took into account employees' Convention rights and future employment prospects (194). But we need to be careful here. The European Court has indeed checked that there has been some kind of weighing. For example, it ruled against a Catholic church that dismissed its organist for leaving his wife and starting a new relationship, on the grounds that his interests had not been taken into account. ${ }^{13}$ But the Court has not sought to establish whether the balance struck by associations is

13 Scüth v. Germany (2011) 52 EHRR 32. 
all-things-considered justified. It has not engaged in a weighing process itself. Associations have a wide margin of appreciation here-they must take employees' interests into account, but the Court will not judge whether their balancing of those interests against the reasons for dismissal was overall justified, since this would infringe coherence and competence interests.

I think this approach, which places strict limits on substantive examination, is correct. The aim is not to assess whether the association interpreted its doctrines correctly, had objectively good reasons for its decision, or accurately weighed those reasons against the employee's interests. Instead, the aim is to check that its stated reasons were not mere pretext, and that it engaged in some basic balancing of relevant interests.

This brings us back to the practical concern I touched upon earlier. To what extent can courts make the kinds of judgments that the framework I have sketched deems permissible without slipping into objectionable forms of assessment? For example, can the requirement that associations give reasons be maintained without becoming a requirement that they give reasons the court considered sufficient or just? Will the requirement of minimal balancing inevitably result in the court imposing its own balance? These questions obviously cannot be answered in the abstract. Recent European Court jurisprudence suggests that courts can make these distinctions, and thus adjudicate such cases without violating coherence or competence interests. But it is too soon to know whether this can be maintained over time.

A final question, therefore, is which way we should hedge things, if courts are likely to overstep the bounds. Should we place stricter limits on court examinations than are ideally required, in order to ensure protection for associational freedom? Or should we hedge in favour of employees, in order to more effectively fight discrimination and wrongful dismissal? Laborde and I might lean in different directions here. I would tend toward limiting courts in the name of associational freedom. Indeed, I think that even a strict jurisdictional bar such as the US 'ministerial exception' might be acceptable for really core cases of a church dismissing a minister. Laborde would probably think this goes too far.

This final comment supports what I said at the outset: that while I do not have fundamental disagreements with Laborde's approach to collective religious liberty, the differences I have highlighted in how we interpret coherence interests and operationalize respect for competence interests might prove very significant in practice. While her ideal state would look a 
lot like Secularia in this domain, mine will be somewhat further along the spectrum toward Divinitia.

\section{Acknowledgments}

[Removed for peer review.]

\section{References}

Laborde, Cécile. 2015. "Religion in the Law: The Disaggregation Approach," Law and Philosophy 34(6): 581-600.

Laborde, Cécile. 2017. Liberalism's Religion. Cambridge, Mass.: Harvard University Press.

Schwartzman, Micah, Chad Flanders, and Zoë Robinson, eds.. 2016. The Rise of Corporate Religious Liberty. New York, NY: Oxford University Press.

Shorten, Andrew. Forthcoming. "May Churches Discriminate?" Journal of Applied Philosophy.

Wolterstorff, Nicholas. 2012. The Mighty and The Almighty: An Essay in Political Theology. Cambridge: Cambridge University Press.

\section{Court cases:}

Lombardi Vallauri v. Italy, App no 39128/05 (ECtHR, 20 October 2009).

Obst v. Germany, App no 425/03 (ECtHR, 23 September 2010).

Siebenhaar v. Germany, App no 18136/02 (ECtHR, 3 February 2011).

Scüth v. Germany (2011) 52 EHRR 32.

Masterpiece Cakeshop v Colorado Civil Rights Commission, 584 U.S. (2018). 